\title{
Absorption removal of hydrogen sulfide from recirculated biogas
}

\author{
Nikolas Gróf, Jana Barbušová, Kristína Hencelová, Miroslav Hutňan \\ Department of Environmental Engineering, Faculty of Chemical and Food Technology, \\ Slovak University of Technology, Radlinského 9, 81237 Bratislava, Slovak Republic \\ nikolas.grof@stuba.sk
}

\begin{abstract}
This study is focused on the effect of biogas recirculation with hydrogen sulfide removal on anaerobic treatment of sulfur-enriched synthetic wastewater in a UASB reactor. The presence of hydrogen sulfide in biogas causes problems in its further energy recovery while sulfides inhibit the anaerobic process. The reactor was gradually loaded with sulfates and their effect on the reactor operation was monitored. At the same time, external absorption of hydrogen sulfide from biogas with absorbent regeneration was operated. The results show that low concentrations of added sulfates support biogas production. At the sulfate concentration of $125 \mathrm{mgl}^{-1}$, biogas production increased by approximately $2 \mathrm{ld}^{-1}$. However, further increasing of the amount of sulfates in the substrate led to the opposite effect. At twice the amount of sulfates, the biogas production decrease by $1 \mathrm{ld}^{-1}$ and its adverse effects on the removal of $\mathrm{N}-\mathrm{NH}_{4}, \mathrm{~N}_{\mathrm{C}}$ and $\mathrm{P}_{-} \mathrm{PO}_{4}$ were observed. Biogas recirculation through the absorption column ensured a decrease in the hydrogen sulfide concentration from $19960 \mathrm{ppm}$ to $4030 \mathrm{ppm}$ and an increase in the methane content from $59.2 \%$ to $83 \%$ and also a decrease in the sulfides concentration in the reactor. From the measured data it can be concluded that this method reduces sulfides inhibition.
\end{abstract}

Keywords: absorption, anaerobic digestion, hydrogen sulfide, UASB reactor

\section{Introduction}

Anaerobic digestion is the decomposition of biomass by microorganisms under anaerobic condition, i.e. without oxygen. In the process, four sets of biochemical reactions can be recognized: hydrolysis, acidogenesis, acetogenesis and methanogenesis (Kadam and Panwar, 2017). During the process of anaerobic digestion $(\mathrm{AD})$ of solid waste and wastewater, biogas, a renewable energy source, is produced (Watsuntorn et al., 2019). Biogas consists of $50-70 \%$ of methane $\left(\mathrm{CH}_{4}\right)$ and $30-50 \%$ of carbon dioxide $\left(\mathrm{CO}_{2}\right)$ and of a small portion of other compounds, such as $0-3 \%$ of nitrogen $\left(\mathrm{N}_{2}\right), 5-10 \%$ of water vapor $\left(\mathrm{H}_{2} \mathrm{O}\right), 0-1 \%$ of oxygen $\left(\mathrm{O}_{2}\right)$, $0-20000 \%$ of hydrogen sulfide $\left(\mathrm{H}_{2} \mathrm{~S}\right)$ depending on the feedstock origin (Angelidaki et al., 2018). Industries, such as paper, textile and pharmaceutical, produce sulfate-rich wastewater which is reduced to sulfides, including gaseous hydrogen sulfide $\left(\mathrm{H}_{2} \mathrm{~S}\right)$, during anaerobic treatment and causes process inhibition due to toxicity to methanogens (Pokorna-Krayzelova et al., 2017). $\mathrm{H}_{2} \mathrm{~S}$ is one of the most common biogas pollutants causing corrosion to internal combustion devices and industrial pipes (Maizonnasse et al., 2013). It is deadly for humans at the concentration of $300 \mathrm{ppm}$ (Aita et al., 2016). The upper limit of $\mathrm{H}_{2} \mathrm{~S}$ concentration permissible for the combined heat and power engines is in the range of 100-500 ppm. Therefore, hydrogen sulfide has to be removed from the biogas (San-Valero et al., 2019). Hydrogen sulfide can be removed from contaminated streams (liquid or gaseous) by physico-chemical (adsorption, precipitation, etc.) or biological methods. Physico-chemical methods are energy-intensive and expensive because they are carried out under high temperatures and pressures and also additional chemicals are needed. In contrast, biological methods employ biochemical oxidation of sulfides to sulfates, thiosulfates or elemental sulfur and thus they have lower operating cost with lower or no addition of chemicals (Krayzelova et al., 2014).

Hydrogen sulfide has an inhibitory or toxic effect on methanogenic organisms, especially in its undissociated form. The free $\mathrm{H}_{2} \mathrm{~S}$ molecule penetrates the cell wall directly into the cell and its inhibitory effects are manifested immediately after the cytoplasm is overcome. $\mathrm{H}_{2} \mathrm{~S}$ inhibits protein production, deactivates various coenzymes in the cell and interferes with the assimilative metabolism of sulfur. To reduce this impact, in situ methods as microaeration and precipitation, dilution with water and a co-fermentation with a low sulfur content substrate to increase the C:N ratio can be used (Hutňan et al., 2016; Krayzelova et al., 2015). Hutňan et. al. (2016) used precipitation to control sulfide inhibition in anaerobic treatment of waste biomass from the production of cystine with high sulfur content about $6 \%$ of total dry matter. Chávez Fuentes J.J. et al. (2015) also investigated the possibility of using dilution of waste biomass from cystine production to reduce sulfide inhibition. 
Biogas recirculation to reduce sulfide toxicity in the anaerobic system was used by Olivier et al. (2020) who investigated the use of four different woodderived biochar types (softwood and hardwoodderived biochar produced at $550{ }^{\circ} \mathrm{C}$ and $800{ }^{\circ} \mathrm{C}$ ) to alleviate sulfide toxicity to methane producing archaea (MPA) and sulfate-reducing bacteria (SRB) during anaerobic treatment of sulfate rich wastewater.

Wang et al. (2003) investigated dosing of oxygen for the oxidation of sulfides into recycled biogas. Oxygen dosing was controlled by oxidation-reduction potential (ORP).

The aim of this work was to study the impact of hydrogen sulfide removal technology in recirculated biogas on reducing sulfide inhibition of anaerobic processes.

\section{Materials and Methods}

The experiment was performed in a upflow anaerobic sludge blanked (UASB) reactor (Fig. 1) with the operating volume of $3.9 \mathrm{l}$. This reactor was inoculated with anaerobic sludge from the wastewater treatment plant (WWTP) Devínska Nová Ves, with the initial total solid concentration of $19.48 \mathrm{~g} \cdot \mathrm{l}^{-1}$ and the volatile solids concentration of $8.24 \mathrm{~g} \cdot \mathrm{l}^{-1}(57.7 \%)$. The reactor was operated at mesophilic condition $\left(37^{\circ} \mathrm{C}\right)$ and $\mathrm{pH}$ of the sludge was 7.82. Volume flow rate of the substrate during the process increased gradually to $6.5 \mathrm{l} \cdot \mathrm{d}^{-1}$, which represents the hydraulic retention time of 14 hours. A synthetic substrate consisting of glucose, sodium acetate, macro- and micronutrients was fed to the bottom of the reactor using a peristaltic pump. The substrate advanced up through a sludge bed formed by a layer of biomass. At the top of the reactor, biomass and biogas were separated from the treated water using a gas-liquid-solids separator (G-L-S separator). The amount of biogas was measured using a drum gas meter. Upon completion of the reactor start-up phase, sulfur was added to the system as sodium sulfate. At the same time, external absorption of hydrogen sulfide was started with absorbent regeneration. At the top of the reactor, a separating element was introduced to ensure biogas recirculation and simultaneous measurement of the produced biogas. Recirculation was provided by a peristaltic pump that pumped biogas through a counter-current absorption column packed with plastic tubes to increase the surface for the phase transfer of hydrogen sulfide from biogas to water, which was used as the absorption agent. Purified biogas was fed back through the partition element to the top of the reactor (fig. 1).

Water enriched with hydrogen sulfide was drained gravitationally to an aerated regeneration column providing oxidation. It was passed through a settling tank and accumulated in a beaker from where it was pumped back to the absorption column.

During the long-term operation of the laboratory model, parameters such as $\mathrm{pH}$, chemical oxygen demand (COD), ammonia nitrogen $\left(\mathrm{N}_{-} \mathrm{NH}_{4}\right)$, orthophosphate-phosphorus $\left(\mathrm{P}_{-} \mathrm{PO}_{4}\right)$, volatile fatty acids (VFA), sulfides $\left(\mathrm{S}^{2-}\right)$ and sulfates $\left(\mathrm{SO}_{4}{ }^{2-}\right)$ concentrations were monitored in the anaerobic reactor

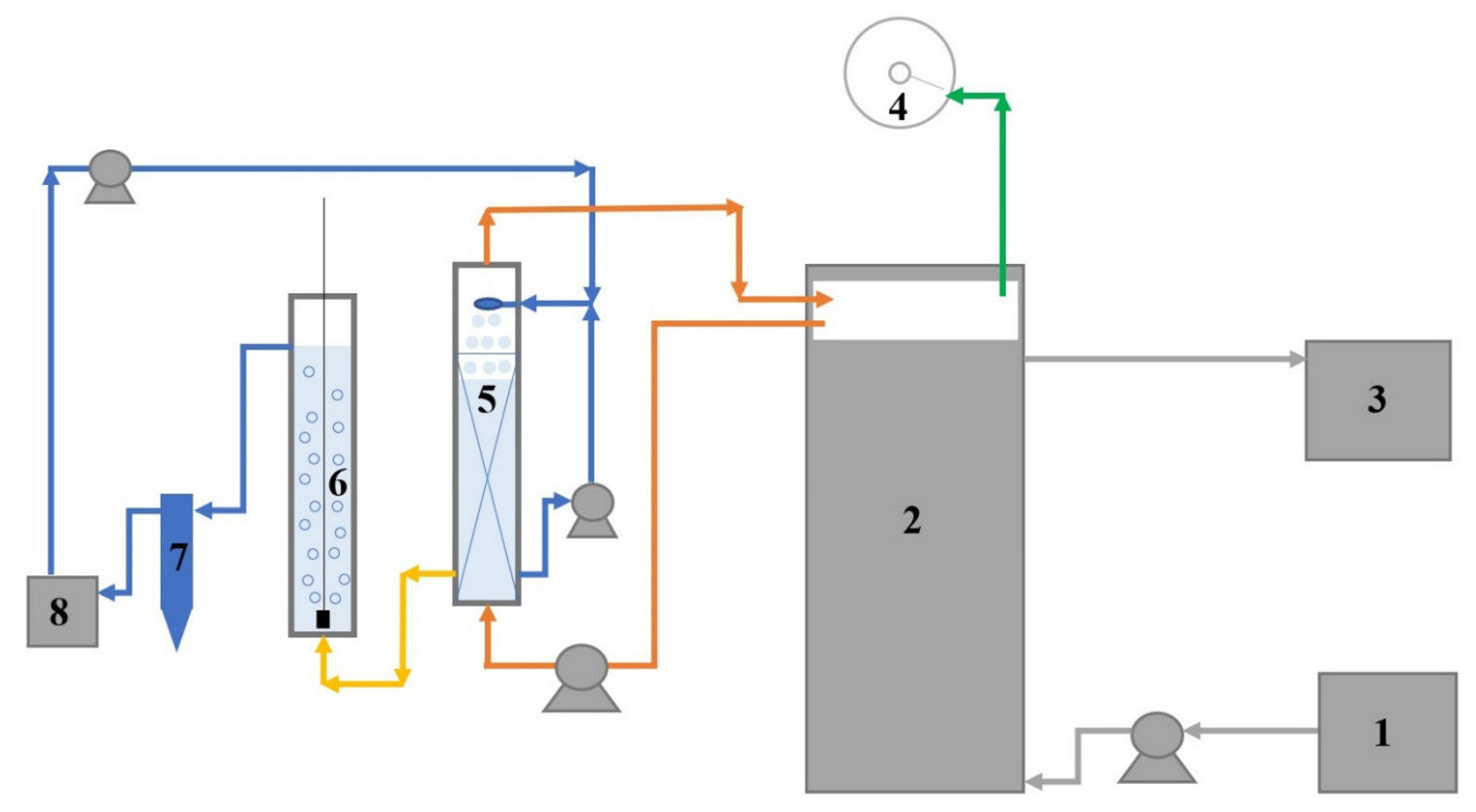

Fig. 1. Laboratory UASB reactor with external removal of hydrogen sulfide from recirculated biogas: 1 - tank for substrate, 2 - UASB reactor, 3 - tank for effluent, 4 - drum gas meter, 5 - counter-current absorption column, 6 - regeneration column, 7 - settling tank, 8 - tank for regenerated water. 
(filtered sample) according to APHA, AWWA, WEF (2017). In addition, the amount of biogas (drum gas meter type AMS Spectrum TCM 143/10 - 4726) produced at laboratory temperature and its composition were measured using a gas analyzer GA 2000 Plus (Geotechnical Instruments, UK).

\section{Results and Discussion}

Start-up of UASB reactor was initiated at the organic load rate (ORL) of $0.5 \mathrm{~kg}(\mathrm{COD}) \cdot \mathrm{m}^{-3} \cdot \mathrm{d}^{-1}$. Successful granulation was reached within 218 day, subsequently, 21 of sludge were withdrawn from the reactor for the maximum specific methanogenic activity test (MSMA), which was performed according to Hussain and Dubey (2014). From the experimental values, the value of MSMA was calculated to be $0.589 \mathrm{~kg} \cdot \mathrm{kg}^{-1} \cdot \mathrm{d}^{-1}$, which represents five times higher methanogenic activity of anaerobic biomass compared to suspended anaerobically stabilized biomass. The mean values of methanogenic activity for stabilized sludge are up to $0.1 \mathrm{~kg} \cdot \mathrm{kg}^{-1} \cdot \mathrm{d}^{-1}$. After completion of the MSMA tests and stabilization of biogas production, the reactor was operated in three phases.

The first phase began on the $224^{\text {th }}$ day when sulfur was added to the reactor. This phase lasted for 20 days, during which synthetic substrate with the sulfate concentration of $125 \mathrm{mg} \cdot \mathrm{l}^{-1}$ was continuously dosed. Biogas production and composition was measured and qualitative analyzes of the sludge water leaving the reactor were done. Fig. 2 shows that low sulfate concentration has a positive effect on biogas production. Production was in the range of $16-17 \mathrm{l} \cdot \mathrm{d}^{-1}$, which is approximately $1 \mathrm{l} \cdot \mathrm{d}^{-1}$ higher than before the sulfate addition to the reactor $\left(15-16 \mathrm{l} \cdot \mathrm{d}^{-1}\right)$. These results were confirmed by the tests of biochemical methane potential (BMP). In Fig. 3, concentrations of the quality parameters at the reactor outlet are presented, which indicate that this concentration does not affect the removal of ammonia nitrogen $\left(\mathrm{N}-\mathrm{NH}_{4}\right)$, total nitrogen $\left(\mathrm{N}_{\mathrm{C}}\right)$ or orthophosphate-phosphorus $\left(\mathrm{P}-\mathrm{PO}_{4}\right)$ : $\mathrm{N}-\mathrm{NH}_{4}$ concentration ranged from $10-25 \mathrm{mg} \cdot \mathrm{l}^{-1}, \mathrm{~N}_{\mathrm{C}}$ concentration was $40 \mathrm{mg} \cdot \mathrm{l}^{-1}$, and $\mathrm{P}_{-} \mathrm{PO}_{4}$ concentration was approximately $9 \mathrm{mg} \cdot \mathrm{l}^{-1}$.

The second phase of the process began on day 245 when the sulfate concentration was increased to $250 \mathrm{mg} \cdot \mathrm{l}^{-1}$. Fig. 2 shows that this concentration already affects the process. Biogas production decreased to its original value $\left(15-16 \mathrm{l} \cdot \mathrm{d}^{-1}\right)$. The presence of sulfates in the wastewater causes a change in the metabolic pathways in the anaerobic reactor due to competition for substrate between sulfate-reducing bacteria (SRB) and fermentative, acetogenic and methanogenic microorganisms. The degree of this competition is mainly related to the $\mathrm{pH}$ and the $\mathrm{COD} / \mathrm{SO}_{4}{ }^{2-}$ ratio in the wastewater. Preferably, SRBs oxidize methanogenic substrates thereby reducing biogas production. From Fig. 3 it can be concluded that increasing the concentration of sulfates has an adverse effect on the removal of $\mathrm{N}_{-} \mathrm{NH}_{4}$ and $\mathrm{N}_{\mathrm{C}}$. The concentration of $\mathrm{N}^{-\mathrm{NH}_{4}}$ at the reactor outlet ranged from 30 to $45 \mathrm{mg} \cdot \mathrm{l}^{-1}$, which is approximately double compared with the first phase $\left(10-25 \mathrm{mg} \cdot \mathrm{l}^{-1}\right)$. The same trend was observed for $\mathrm{N}_{\mathrm{C}}$ with the concentration ranging from 50 to $70 \mathrm{mg} \cdot \mathrm{l}^{-1}$. The $\mathrm{P}_{-} \mathrm{PO}_{4}$ concentration increased only slightly, from $9 \mathrm{mg} \cdot \mathrm{l}^{-1}$ to $13 \mathrm{mg} \cdot \mathrm{l}^{-1}$. From the beginning of the second phase, the outlet concentration of sulfates was also monitored and it was approximately $40 \mathrm{mg} \cdot \mathrm{1}^{-1}$.

On day 265, the sulfate concentration was increased to $700 \mathrm{mg} \cdot \mathrm{l}^{-1}$ to initiate the third phase of the UASB reactor operation. This concentration already slightly inhibited the whole process, as it can be seen in Fig. 2. Biogas production decreased, which was also expected based on the BMP tests performed. The decrease in biogas production was about $2-4 \mathrm{l} \cdot \mathrm{d}^{-1}$. The outlet parameters (Fig. 3) indicate deterioration of the quality of the outlet sludge water. The concentration of $\mathrm{N}-\mathrm{NH}_{4}$ ranged from 50 to $90 \mathrm{mg} \cdot \mathrm{l}^{-1}$ while that of $\mathrm{N}_{\mathrm{C}}$ ranged from 60 to $100 \mathrm{mg} \cdot \mathrm{l}^{-1}$. The adverse effect of high

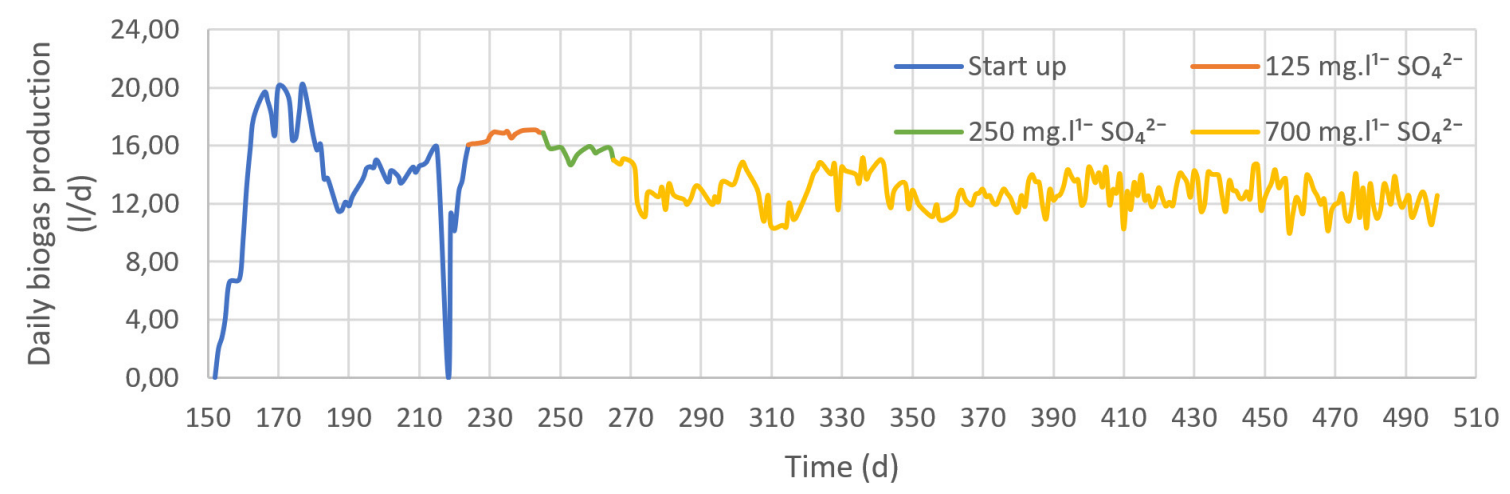

Fig. 2. Daily biogas production at various sulfate concentrations. 


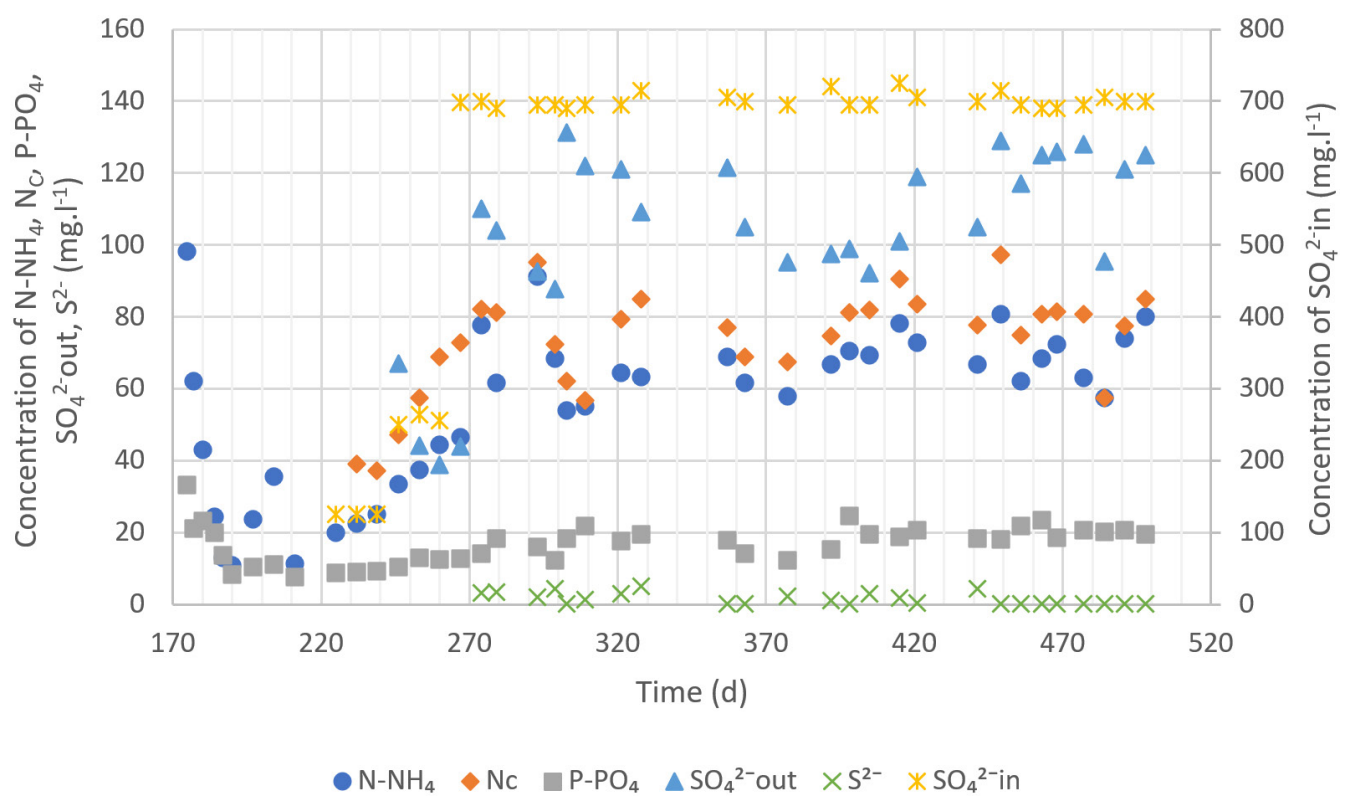

Fig. 3. Qualitative parameters of UASB reactor.

sulfate concentration was also observed through the removal of $\mathrm{P}_{-} \mathrm{PO}_{4}$. The concentration of $\mathrm{P}_{-} \mathrm{PO}_{4}$ at the reactor outlet ranged from 12 to $25 \mathrm{mg} \cdot \mathrm{l}^{-1}$. When comparing the second and third phases, the outlet concentration of all monitored parameters $\left(\mathrm{N}-\mathrm{NH}_{4}, \quad \mathrm{~N}_{\mathrm{C}}, \mathrm{P}_{-} \mathrm{PO}_{4}, \mathrm{SO}_{4}{ }^{2-}\right)$ were approximately doubled. In the third phase, sulfides concentration at the reactor outlet was monitored. During operation, the sulfide concentration in the sludge water did not exceed $5 \mathrm{mg} \cdot \mathrm{l}^{-1}$.

In Fig. 4 shows the $\mathrm{pH}$ value of around 7.5 during the whole operation, only at the beginning of the start-up ( $187^{\text {th }}$ day), the value dropped to 6.5 probably due to the reactor overload. The reac- tor overload also indicates a significant increase in the concentrations of VFA (1 000-1 $\left.200 \mathrm{mg} \cdot \mathrm{l}^{-1}\right)$ and COD (2 000-2 $\left.500 \mathrm{mg} \cdot \mathrm{l}^{-1}\right)$ at the outlet. After stabilization of the system, the VFA concentration decreased below $250 \mathrm{mg} \cdot \mathrm{l}^{-1}$ and the COD removal efficiency was above $90 \%$.

During the reactor operation, the effect of hydrogen sulfide absorption in the recirculated biogas stream on the anaerobic process was assessed. The set values of biogas composition are given in Tab. 1. In the first biogas composition analysis, carried out on the $223^{\text {rd }}$ measurement day, no recirculation occurred and sulfur was not added to the system but biogas contained 780 ppm of hydrogen sulfide.

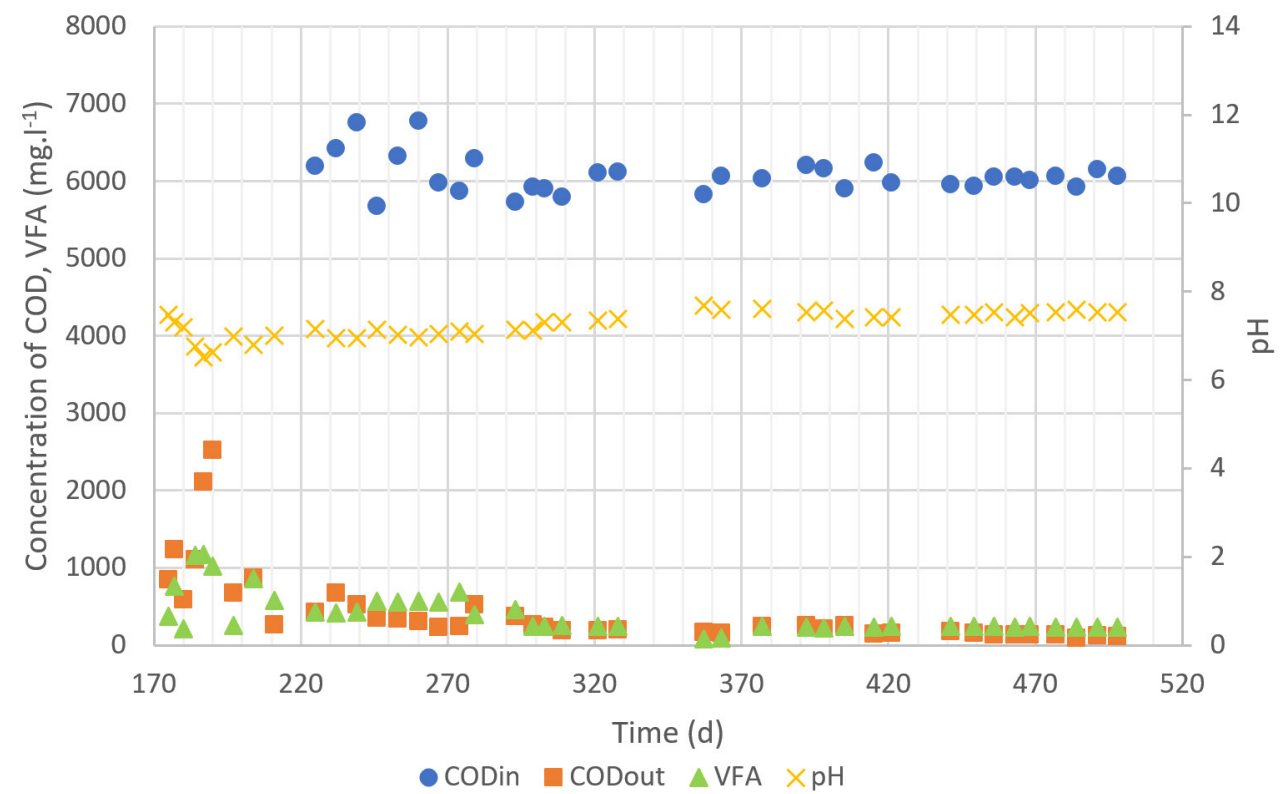

Fig. 4. Inlet concentration of COD, outlet concentration of COD and VFA from reactor, and $\mathrm{pH}$. 
The presence of hydrogen sulfide in the biogas was probably caused by sulfates contained in tap water used to make the synthetic substrate. Subsequent increase in the sulfate concentration to $125 \mathrm{mg} \cdot \mathrm{l}^{-1}$ (first phase) caused an increase in the amount of hydrogen sulfide in the biogas to $3940 \mathrm{ppm}$. Introduction of hydrogen sulfide absorption from recirculated biogas led to a decrease in the hydrogen sulfide concentration by more than a half.

On the next day (day 245), sulfate concentration was increased to $250 \mathrm{mg} \cdot \mathrm{l}^{-1}$ (second phase). After recirculation was interrupted, the quality of biogas further deteriorated. Methane levels dropped below $60 \%$ on day 251. Later that day, recirculation was reintroduced. On day 258, biogas composition was determined. After eight days of hydrogen sulfide absorption in the recirculated biogas stream, the hydrogen sulfide concentration decreased to 3175 ppm. Also, the amount of $\mathrm{H}_{2}$ was reduced to $370 \mathrm{ppm}$. However, the amount of methane decreased to $67.3 \%$. On day 260, recirculation was disconnected and biogas composition was determined four days later. Since the removal of hydrogen sulfide did no longer occur, the amount of hydrogen sulfide increased to $13970 \mathrm{ppm}$. The methane content was approximately the same $(67.2 \%)$ but the amount of hydrogen in biogas increased to $7006 \mathrm{ppm}$.

On day 265, the third phase of reactor operation began when the sulfate concentration was increased to $700 \mathrm{mg} \cdot \mathrm{l}^{-1}$. Biogas was recirculated for nine days and the biogas composition was determined. The amount of hydrogen sulfide increased to 16518 ppm, which could be due to low flow rate of recirculated biogas $\left(10 \mathrm{l} \cdot \mathrm{d}^{-1}\right)$. The next day, the recirculated biogas flow rate was increased to around $30 \mathrm{l} \cdot \mathrm{d}^{-1}$. The absorption column was operated for 20 days followed by re-determination of the biogas composition (day 295). From the measured values (Tab. 1) it can be argued that the increase in the flow rate had a positive effect 0 on the biogas quality. The methane content increased to $78.1 \%$ while the amount of hydrogen sulfide in the biogas decreased to $12890 \mathrm{ppm}$. However, the detected amount of hydrogen sulfide is still high, so the flow rate of recirculated biogas was increased to approximately $65 \mathrm{l} \cdot \mathrm{d}^{-1}$. After 33 days of the absorption column operation, biogas composition was again determined. Increasing the flow rate ensured the decrease of hydrogen sulfide content in the biogas to $7970 \mathrm{ppm}$. Control pH measurement in the recovery column was done. Optimum $\mathrm{pH}$ for sulfates precipitation to elemental sulfur is about 7. However, from the control measurement $\mathrm{pH}$ decrease to 4 was observed. To ensure the required $\mathrm{pH}$ value, sodium hydrogen carbonate was added to the storage tank.

The next biogas composition measurement was performed on day 376. The methane content increased to $83 \%$ and the amount of hydrogen sulfide in the biogas decreased to $4030 \mathrm{ppm}$. The amount of hydrogen in biogas was also reduced to $715 \mathrm{ppm}$. The increased methane concentration in biogas is also caused not only by hydrogen sulfide but also by carbon dioxide absorbed in water. On day 393, biogas recirculation was interrupted and the biogas composition was determined after four days. The methane content decreased to $66.2 \%$, and the amount of hydrogen sulfide increased to $19960 \mathrm{ppm}$. Immediately after the measurement, biogas recirculation was switched back on and on the following day $\left(398^{\text {th }}\right.$ day), biogas composition was measured again. From the results it can be seen that the amount of hydrogen sulfide decreased to

Tab. 1. Biogas composition and sulfide concentration in the reactor.

\begin{tabular}{lc|cccccc}
\hline Recirculation & Day & $\mathbf{C H}_{\mathbf{4}}(\%)$ & $\mathbf{C O}_{\mathbf{2}}(\%)$ & $\mathbf{O}_{\mathbf{2}}(\%)$ & $\mathbf{H}_{2}(\mathbf{p p m})$ & $\mathbf{H}_{\mathbf{2}} \mathbf{S}(\mathbf{p p m})$ & $\mathbf{S}^{2-}\left(\mathbf{m g l} \mathbf{l}^{\mathbf{1}}\right)$ \\
\hline Off & 223 & 68,4 & 32,1 & 0,7 & $<1000$ & 780 & - \\
Off & 230 & 67,6 & 30,2 & 0,7 & $<1000$ & 3940 & - \\
On & 244 & 73,1 & 23,1 & 0,8 & $<1000$ & 1860 & - \\
Off & 251 & 59,2 & 24,6 & 2,7 & $<1000$ & $<5000$ & - \\
On & 258 & 67,3 & 22,4 & 1,7 & 370 & 3180 & - \\
Off & 264 & 67,2 & 31,4 & 0,5 & 7010 & 13970 & 3,17 \\
On & 274 & 68,1 & 26,6 & 0,7 & 6300 & 16520 & 0,00 \\
On & 295 & 78,1 & 16,4 & 0,4 & 9070 & 12890 & 0,00 \\
On & 329 & 78,7 & 16,2 & 0,5 & 4480 & 7970 & 0,00 \\
On & 376 & 83,0 & 10,6 & 0,5 & 715 & 4030 & 0,00 \\
Off & 397 & 66,2 & 17,5 & 1,6 & 27430 & 19960 & 4,18 \\
On & 398 & 73,7 & 14,3 & 1,5 & 7960 & 8400 & 0,00 \\
On & 468 & 77,9 & 16,2 & 0,5 & 9010 & 8760 & 0,00 \\
\hline
\end{tabular}


8400 ppm, which also improved the biogas quality. The methane content increased to $73.7 \%$. The last measurement was made on day 468, when a slight increase in the methane content $(77.9 \%)$ in biogas was observed. The amount of hydrogen sulfide in the biogas remained the same.

\section{Conclusion}

Dosing of sulfates together with synthetic substrate into an UASB rector was found to affect biogas production. In case of low levels of sulfates, a slight increase in biogas production was observed, which confirms the results of biogas potential tests. Before the addition of sulfates, biogas production was $15 \mathrm{ld}^{-1}$. During dosing of the synthetic substrate with the sulfate concentration of $125 \mathrm{mgl}^{-1}$, production increased to approximately $17 \mathrm{ld}^{-1}$. However, further increase in the sulfates concentration caused the biogas production to decrease again. When $700 \mathrm{mgl}^{-1}$ of sulfates were added, the production reached $13 \mathrm{ld}^{-1}$. Also a negative effect on the removal of $\mathrm{N}-\mathrm{NH}_{4}, \mathrm{P}_{-} \mathrm{PO}_{4}$ and other nitrogen compounds was found. The decrease in the removal efficiency of these qualitative indicators was most evident when $250 \mathrm{mgl}^{-1}$ of sulfates were added.

Biogas recirculation with hydrogen sulfide absorption has proven to be an effective method of reducing hydrogen sulfide content in biogas. During the recirculation, concentrations of hydrogen sulfide was reduced and also the biogas quality improved. The highest methane content was $78.7 \%$ and $83 \%$, respectively. Considering hydrogen sulfide content, long-term operation of recirculation led to high efficiency of its removal from biogas. After recirculation was disconnected, the hydrogen sulfide concentration in biogas increased to $19960 \mathrm{ppm}$.

Our aim was to determine the effect biogas recirculation with hydrogen sulfide removal on sulfide inhibition of the anaerobic process. When biogas recirculation was switched off, sulfide concentration in the reactor increased up to $4.18 \mathrm{mgl}^{-1}$. When the recirculation was restarted, a decrease in the sulfide concentration $\left(0 \mathrm{mgl}^{-1}\right)$ was observed, which suggests that the inhibitory effect of sulfides is partially suppressed.

\section{Acknowledgement}

This work was supported by the Slovak Grant Agency for Science VEGA (grant 1/0772/16).

\section{References}

Aita BC, Mayer FD, Muratt DT, Brondani M, Pujol ST, Denardi LB, Hoffmann R, Dias da Silviera D (2016) Clean Technologies and Environmental Policy, 18, 689-703.

Angelidaki I, Treu L, Tsapekos P, Luo G, Campanaro S, Wenzel H, Kougias PG (2018) Biotechnology Advances 36, 452-466.

APHA/AWWA/WEF (2017) Standard Methods for the Examination of Water and Wastewater. American Public Health Association, USA.

Hussain A, Dubey SK (2014) Desalination and Water Treatment 52, 7015-7025.

Hutňan M, Chávez Fuentes JJ, Czölderová M (2016) Applied Mechanics and Materials 832, 122-127.

Chávez Fuentes JJ, Hutňan M, Bodík I, Zakhar R, Czölderová M (2015) Water Science and Technology 72, 585-592.

Kadam R, Panwar NL (2017) Renewable and Sustainable Energy Reviews 73, 892-903.

Khanal SK, Huang JC (2003) Water research 37, 2053-2062.

Krayzelova L, Bartacek J, Kolesarova N, Jenicek P (2014) Bioresource Technology 172, 297-302.

Krayzelova L, Bartacek J, Díaz I, Jeison D, Volcke EIP, Jenicek P (2015) Reviews in Environmental Science and Bio/Technology 14, 703-725

Maizonnasse M, Plante JS, Oh D, Laflamme CB (2013) Renewable Energy 55, 501-513.

Oliviera FR, Surendra KC, Jaisi DP, Lu H, Unal-Tosun G, Sung S, Khanal SK (2020) Bioresource Technology 301, 122711.

Pokorna-Krayzelova L, Mampaey KE, Vennecke TPW, Bartacek J, Jenicek P, Volcke EIP (2017) Biochemical Engineering Journal, 125, 171-179.

San-Valero P, Penya-roja JM, Álvarez-Hornos J, Buitrón G, Gabaldón C, Quijano G (2019) Fully aerobic bioscrubber for the desulfurization of H2S-rich biogas, Fuel 241, 884-891.

Watsuntorn W, Khanongnuch R, Chulalaksananukul W, Rene ER, Lens PNL (2019) Journal of Cleaner Production 249, 119351. 